\title{
Role of parental socioeconomic status on their children's education at District Mardan of Khyber Pakhtunkhwa, Pakistan
}

\author{
Abid Ali ${ }^{1}$, Azizullah Jan ${ }^{1}$, Ihsan Ullah Khan ${ }^{2}$, Alam Zeb ${ }^{3}$, Mansoor Ahmad ${ }^{1}$ \\ ${ }^{1}$ Department of Sociology, University of Peshawar, Pakistan \\ ${ }^{2}$ Department of Sociology, FATA University, TSD Dera MND, Kohat, Khyber Pakhtunkhwa, \\ Pakistan \\ ${ }^{3}$ Center for Education \& Staff Training, University of Swat \\ Correspondence: Azizullah Jan (email: azizj153@gmail.com)
}

Received: 10 July 2020; Accepted: 10 March 2021; Published: 29 May 2021

\begin{abstract}
Education has been unequally disseminated to the deprived class due to socioeconomic that hardly receiving their rational piece. This research study aimed to find out the connection between socioeconomic factors and the academic performance of students in selected higher secondary schools in District Mardan, Khyber Pakhtunkhwa. A sample of 150 students was selected from three schools through the purposive sampling method. Data was collected through a structured questionnaire with five points Likert scale. The descriptive statistic, frequency, percentage and mean was used for basic information while inferential statistics were used for the correlation of the selected variables. The findings show that family size has a negative significant relationship, while parental education, income level and parental assistance have significant and positively related to the child's education. While parental occupation and parental decision have non significant relationship with children educational outcomes. The study outcomes show that there is a significant and positive correlation between the socioeconomic status of the parents with children's academic performance. Consequently, it is suggested that the government has to make available schools that will accommodate and also provide an encouraging environment for all the students regardless of their family socioeconomic status.
\end{abstract}

Keywords: Assistance, decision, education, family, income, occupation

\section{Introduction}

Socio-economic development of a nation directly proportional to the skills and working potential based on educating constellation, because it's an alleyway to national development and it promotes socio-economic and generally national development (World Bank, 2002). Educating masses and levitation of educational accomplishments in schools is the concern of stakeholders. In this respect, gaining access to education has been unequally disseminated to the deprived class that hardly receiving their rational piece (World Bank, 2003). At the moment children are indispensable to society as they are the future of a nation, they hold the key to 
change in their hands. Therefore, it is vital to provide well-organized education to them that teaches them how to work together effectively for development and change (Chen, 2009). This education starts with their parents with what children learn in the initial ages of their lives. This preliminary schooling impacts the rest of their lives and fundamentally shapes society's future. It concludes that early education and family background, especially parents play a substantial role in a child's placement in education. But the family background is a multidimensional factor based on financial, social, educational, traditional, and even other peculiar elements. According to utmost researches done on the family background and children's education, the most dominant elements are a personal, economic and educational qualification of parents. These factors also mainly contribute to the household background that they make available to children. It is essential to recognize that parentages socioeconomic and education are one of the greatest significant elements in their children's education (Trizard, Schofield \& Hewison, 1982). Various studies have reported that the socio-economic and educational status of patients has a massive influence on the educational achievements of a child. To what extent does it influence the academic performance of the children? Consequently, this study sought to institute and dig out the relationship between socioeconomic and parental education in District Mardan Khyber Pakhtunkhwa of Pakistan.

\section{Literature review}

Various research studies have been conducted on the selected factors, but literature displays that the socioeconomic status of the household was reliably found a strong predictor which affect educational results (Fan \& Chen, 2001; Kushner, Benson, Mudrey-Camino \& Steiner, 2010). Students' academic performance has been studied from various and multiple dimensions that children academic performance based on parenting style (Ahmed et al., 2019), students approach towards learning, educational services at schools and teachers assistances and capabilities (Maina, 2010), family socioeconomic position (Hanes, 2008; Pruitt et al., 2019), classroom learning setting, peer group, students inspiration and encouragement, home situation and parental participation in children education (Chen, 2018; Gustavsen, 2018), and partnership between school, family and community (Epstein, 2009). However, research studies found that the above mentioned factors have high influence on students' education and increases students' motivation to complete their academic responsibilities on time and develop their learning habits (WEF, 2017).

According to research studies in western countries, researchers reported that socioeconomic status plays an essential role in children's educational results (Kellaghan, Sloane, Alvarez, \& Bloom, 1993). Further, it was observed that the higher socioeconomic status of the student family may lead to higher academic performance (Lanham, 2002). Furthermore, studies howed that School-based parental involvement is higher among those with higher income than lower income (Hill \& Taylor, 2004; Hornby \& Blackwell, 2018).

While, parents with low incomes, working long hours and earn small salaries having less time for their children to involve in their learning process. Additionally, conflict in homes of lower-income may cause stress within the family, which resulting in poor academic performance (Saifi \& Mehmood, 2011; Sirin, 2005). Different other research studies established that student's enrollment, retention, and study completion can extremely be influenced by the lower level of socio-economic status of the parents (Birdsall et al., 2005; Bruneforth, 2006; Cardoso \& Verner, 2007; Wang, 2010). A survey was conducted by parents and guardians in Tanzania regarding the financial conditions of children's school enrollment. Their responses were no more than the economic issue that may cause children to drop out of school (Dachi \& Garrett, 2003). 
Alongside, children's education is not merely influenced by a parent's personal and socioeconomic status, but educational conditions and personal experiences are highly connected to their children's education. Since parents are considered as a second teacher to guide and provide all the required and allied materials to the child to perform well in their field (Taiwo, 1993). While on the other side research also indicates that parent's literacy level can strongly affect their child's education. There is strong evidence that parents who are highly educated, socially and economically rigorous may promote a higher level of achievements for children (Mukherjee, 1995).). Further results show that parents who have attained high school education were reported to be more involved with their children's academic activities than those who did not finish high school (Rothestein, 2004). Consequently, students whose parents have a higher level of education may have higher opportunities for learning, more progressive ability, strong work placement and they may use more active learning schemes than those whose parents with lesser levels of education (Jeynes, 2002). Besides, children who belong to a well-educated family perform better than those who have an illiterate family background. Because a child from an educated household has greater support such as a good educational setting, well-equipped study materials, parental guidance, and support in education (Jeynes, 2007).

Another study also limelight the significance of parental education for children, as those parents who attend and finished senior four and sixth grade or university level education may achieve significantly than those students whose parents did not complete or just finished the primary level. Whereas, those students whose parents had a university-level degree may perform well and got more test scores due to effective helping by their parents in their academic work (Omoegun, 2007). In parental education, especially the mother's education level has significant impacts on the learning process that influence the child's academic level and other school achievements. Most research studies reveal that highly educated mothers have greater success in helping and providing basic cognitive learning skills that directly contribute to child education (Guerin et al., 2001). But in contrast, parents who belong to low educational background did not give apposite attention to support and administer their child's performance due to the absence of suitable information and experience to face the challenges which dismay children and may lead to drop-out from school (Adewale, 2002; Poston \& Falbo, 1990).

\section{Methods and materials}

This study was conducted in three (2 Male and 1 Girls school) selected Government Higher Secondary Schools (12 $2^{\text {th }}$ class) out of six (4 male and 2 female schools) in Tehsil Takht Bhai, District Mardan Khyber Pakhtunkhwa of Pakistan. Data was collected through purposive sampling technique from a total of 150 students. From each school, 50 students (25 A grade (more than 75\% marks) and $25 \mathrm{~B}$ grade (Below 60\% Marks) were carefully chosen with the help of the last term examination record from different disciplines (Science and Arts group) and interviewed by a structured questionnaire. The questionnaire was structured, and the Likert scale was used in such a way that the respondents were selected one of them which they considered right. The questionnaire consisted of three sections; first biographic information, the second socioeconomic status of parents, and third child academic achievements. However, a questionnaire based on previous literature and some items were adopted from Lareau, (2000) and were modified according to research objectives. The scoring technique was adopted for response counting. The participants expressed their opinion for each item from 1 to 5 (strongly disagree to strongly agree) on a Likert scale and converted into numerical values 1, 2, 3, 4, and 5 respectively. The greater score points out the high influence of those items; a mean score of 3.0 or higher indicates a high; while a mean score of 2.0 or less shows little influence of the 
selected variables. After the data collection process, it was systematically punched into the SPSS sheet to analyze them to dig out the key outcomes. The obtained data was statistically analyzed by using frequency, the percentage for demographic variables. While the correlation coefficient test was used for the relationship between variables.

\section{Results and discussion}

Table 1 presents the demographic information of the study participants. In which $66 \%$ were male students and 33\% were female students. In the age group, 64\% were from the 16-19 age group, $20 \%$ from the $20-23$ age group and only $6 \%$ from above 27 years. While in parents' education, $7 \%$ of the fathers and $42 \%$ mothers never went to school and illiterate while $37 \%$ of the father and $25 \%$ mothers completed their metric level education. Moreover, only $2 \%$ of the parents completed and get a higher education. The results show that $20 \%$ of fathers and $39 \%$ of mothers of the children in this study were unemployed and only $36 \%$ of fathers and $22 \%$ of mothers were government servants. At the parent's income level, $18 \%$ of fathers and $44 \%$ of mothers have 10000 to 20000 monthly incomes. While $44 \%$ of fathers and $26 \%$ of mothers have 20000 to 30000 monthly income. Further, in living, majority $89 \%$ were living with mother and father and only $2 \%$ were living with their relatives. In the family structure, $84 \%$ were living in a nuclear family, and only $2 \%$ living in an extended family. In the size of family member majority, 59\% have 4-6 family members and 23\% were having only 3 members of their family. The results also show the academic achievements, in which the majority $32 \%$ got $71-80 \%$ marks in last final exam while $4 \%$ got below $50 \%$ marks.

Table 1. Basic information of respondents

\begin{tabular}{|c|c|c|c|}
\hline Items & Categories & Frequency & Percentage \\
\hline \multirow{2}{*}{ Gender } & Male & 100 & 66.66 \\
\hline & Female & 50 & 33.33 \\
\hline \multirow{4}{*}{ Respondent's Age } & $16-19$ & 96 & 64 \\
\hline & $20-23$ & 30 & 20 \\
\hline & $24-27$ & 15 & 10 \\
\hline & Above 27 & 9 & 6 \\
\hline \multirow{6}{*}{ Father/Mother's education level } & Illiterate & $11 / 64$ & $7 / 42$ \\
\hline & Metric & $56 / 38$ & $37 / 25$ \\
\hline & FA & $22 / 12$ & $14 / 8$ \\
\hline & $\mathrm{BA}$ & $31 / 21$ & $20 / 14$ \\
\hline & MA & $26 / 12$ & $17 / 8$ \\
\hline & Higher Education & $4 / 3$ & $2 / 2$ \\
\hline \multirow{4}{*}{ Father/ Mother's Occupation } & Unemployed & $31 / 59$ & $20 / 39$ \\
\hline & Govt. servant & $54 / 34$ & $36 / 22$ \\
\hline & Non Govt. servant & $46 / 42$ & $30 / 28$ \\
\hline & Own business & $19 / 15$ & $12 / 10$ \\
\hline \multirow{4}{*}{ Father/Mother monthly Income level } & $10,000-20,000$ & $28 / 67$ & $18 / 44$ \\
\hline & $20,001-30,000$ & $66 / 39$ & $44 / 26$ \\
\hline & $30,001-40000$ & $39 / 28$ & $26 / 18$ \\
\hline & Above 40,000 & $17 / 16$ & $11 / 10$ \\
\hline \multirow{4}{*}{ With whom do you live } & Both father \& mother & 134 & 89 \\
\hline & Father's only & 4 & 2 \\
\hline & Mother's only & 8 & 6 \\
\hline & With relatives & 4 & 2 \\
\hline \multirow{3}{*}{ Type of family } & Nuclear Family & 126 & 84 \\
\hline & Joint Family & 21 & 14 \\
\hline & Extended Family & 3 & 2 \\
\hline Number of family members, including you & 3 only & 35 & 23 \\
\hline
\end{tabular}




\begin{tabular}{llrr} 
& $4-6$ & 89 & 59 \\
& $7-9$ & 26 & 18 \\
& Below 50\% & 7 & 4 \\
Percentage in Last final exam & $51-60 \%$ & 34 & 22 \\
& $61-70 \%$ & 32 & 21 \\
& $71-80 \%$ & 49 & 32 \\
& Above $80 \%$ & 28 & 18 \\
\hline
\end{tabular}

Table 2 shows and evaluated the study respondents' parental socioeconomic status. The mean (M) and standard deviation (S.D) for each item are provided in the above table to find its average mean. Parental income got the mean score $(M=4.1$; S.D=2.189) which shows that parents' level of income influences children's academic achievements. It was observed that the higher income status of the student family may lead to higher academic performance (Peters, $\&$ Mullis, 1997). While the parental occupational status got a low score $(M=2.92)$ which shows that it does not influence the academic career of the child. Further parents' educational level influenced to achieve a score $(M=3.97)$ which shows that it influenced the child's education up to a great extent. However, educated parents assist children with school homework got scored $(M=3.1)$. Whereas, the previous study also shows that those students whose parents are educated may perform well and got more test scores due to effective helping by their parents in their academic work (Hoover-Dempsey, Basslet, \& Brissie, 1987). Besides, educated parents make the best decisions for their children's future children got a score $(M=4.32)$. Educated parents provide the best level of guidance to their children for examination scores $(\mathrm{M}=3.98)$.

Table 2. Uni-Variate Analysis of parental socio-economic status

\begin{tabular}{lcc}
\hline Items & Mean & St. Deviation \\
\hline $\begin{array}{l}\text { Parent's income level influenced academic achievement } \\
\text { Parents' occupational status influenced academic }\end{array}$ & 2.1 & 2.189 \\
achievement & & 0.198 \\
Parents' educational level influenced academic achievement & 3.97 & 1.132 \\
Educated parents assist children with school homework & 3.1 & 1.39 \\
$\begin{array}{l}\text { Educated parents make the best decisions for their children future } \\
\text { Educated parents provide the best level of guidance for }\end{array}$ & 4.32 & 1.222 \\
examination & & 1.129 \\
\hline
\end{tabular}

Table 3 shows the Pearson correlation coefficient of the parental socio-economic status and impacts on their child's education. There is negative significant correlation between number of family members/family size and students' academic performance ( $\mathrm{r}=-0.691$; $\mathrm{p}=0.000$ ) at 0.05 level of significance. While there was a strong positive significant correlation between the parental level of education and children's academic achievements $(\mathrm{r}=0.884$; $\mathrm{p}=0.000$ ). The previous study of Glewwe, \& Jacoby (1995); Izzo, Weissberg, Kasprow, \& Fendrich, (1999) also found that that kid whose parenthoods have a greater level of education are more focused on their children's learning as associated with those children whose parents have lower levels of education. Further, a parent's income level significant impact ( $\mathrm{r}=0.858$; $\mathrm{p}=0.000$ ) on children education. Because the earlier studies collected by Hill et al., (2004); Omoegun, (2007) findings have constant results that the high-income level of parents influences a durable predictor of children's success and academic achievements. 
Table 3. Correlation between Socio-economic and children academic achievements

\begin{tabular}{lll}
\hline Items & r value & p-value \\
\hline Family size & -.691 & $0.000^{* *}$ \\
Parents' educational level & .884 & $0.000^{* *}$ \\
Parent's income level & .858 & $0.000^{* *}$ \\
Parents' occupational status & 0.29 & 0.123 \\
Educated parents assistance & .779 & $0.000^{* *}$ \\
Educated parents decisions & .675 & .021 \\
Educated parents guidance & .609 & $0.002 * *$ \\
\hline
\end{tabular}

There is a non-significant week correlation $(\mathrm{r}=0.29 ; \mathrm{p}=0.123)$ between parent's occupational status and children's education. This shows that parents' occupation does not influence children's education. The educated parents' assistance in the study has a strong significant relationship $(\mathrm{r}=0.779 ; 0.000)$ with children's education because the parents help overcome the difficulties that faced by their children in their studies and homework. Educated parents make the best decisions for their children's future has non-significant $(r=0.675$; $\mathrm{p}=0.021$ ) relation to the children's education.

The results of the current study are negating the research studies conducted by (Currie, (1977); Eamon, (2005); Ermisch, \& Francesconi, (2001), which advocated that those parents who are involved in inspiring their children, talk over their future academic plan, and school homework have positive effects on children. Whereas, educated parents provide the best level guidance for examination has a moderately but significant relationship $(r=0.609 ; p=0.002)$ with children's education. The study of Jezierski and Wall (2019) found that educated parents facilitating children plan out time to do coursework and observing over homework assignments. Moreover, reseach study carried out that students from very educated parents attained greater academic scores than students of little educated or illiterate parents (Bakar et al., 2017). The results of Bierman et al. (2015) supported the results that the level of parental education is the key element in children's educational performance and how educated parents use home learning resources to outline the academic performance of their children. While, uneducated parents are hesitant to be indulged in such practices due to their low level of education.

\section{Conclusion}

The research study was conducted about the influence of parental socio-economic status on their children's education at District Mardan. The data were conducted with 150 respondents in three selected Higher Secondary Schools. The results show that the majority were male and have a strong academic position. Moreover, the study outcomes show that family size and family income have significantly affected children's education. It shows that family income is an excessive factor that plays a significant role in children's academic performance. While the low income of the parents is a leading difficulty in educational achievement and development of the children. Likewise, those children whose parents have a high level of education and parental assistance in school activities has a significant relationship and better children academic performance. While no significant relationship was found between children's education and parental occupation and parental decision regarding plans for the study. This study concluded that socio-economic and other mentioned related factors play a magnificent role in children's academic achievements. Therefore, this study recommended that government should take some thoughtful initiatives in raising the socio-economic status of people to promote education and national development. 


\section{References}

Adewale, A. M. (2002). Implication of parasitic infections on school performance among school-age children. Ilorin Journal of science education, 2(6), 78-81.

Ahmed, G., Muhammad, A., Zia, A. Q., \& Muhammad, A. (2019). Effects of parent attitude on secondary school students academic performance in Pakistan. Ind. J. Sci. Technol, 12(6), 1-9.

Bakar, N.A., Ibrahim, M., \& Mudassir, I. (2017). Influence of parental education on academic performance of secondary school students in Kuala Terengganu. Int. J. Acad. Res. Bus. Soc. Sci. 7(8), 296-304.

Bierman, K. L., Welsh, J. A., Heinrichs, B. S., Nix, R. L., \& Mathis, E. T. (2015). Helping head start parents promote their children's kindergarten adjustment: The researchbased developmentally informed parent program. Child development, 86(6), 1877 1891.

Birdsall, N., Levine, R., \& Ibrahim, A. (2005) Towards universal primary education: investments, incentives, and institutions. European Journal of Education, 40(3), 337349.

Bruneforth, M. (2006) Characteristics of children who drop out of school and comments on the drop-out population compared to the population of out-of school children. Background paper for the EFA Global Monitoring Report 2007.

Cardoso, A. R., \& Verner, D. (2007) School drop-out and push-out factors in Brazil: The role of early parenthood, child labor, and poverty. IZA Discussion Paper No 2515. Bonn: Institute for the Study of Labour (IZA).

Chen, G. (2008). Parental involvement is key to student success. Public School Review.

Chen, H. (2009). The longitudinal factor structure of parent involvement and its impact on academic performance. Proquest dissertation, University of Denver, Denver, Colo, USA.

Currie, J. (1977). Family Background, Academic Achievement and Occupational Status in Uganda. Comparative Education Review, 21(1), 14-28.

Dachi, H. A., \& Garrett, R. M. (2003). Child Labour and its Impact on Children's Access to and Participation in Primary Education: A Case Study from Tanzania. London: DFID

Eamon, M. K. (2005). Social-demographic, school, neighborhood, and parenting influences on academic achievement of Latino young adolescents. Journal of Youth and Adolescence 34(2), 163-175.

Epstein, J. L., Sanders, M. G., Sheldon, S. B., Simon, B. S., Salinas, K. C., Jansorn, N. R., ..., \& Williams, K. J. (2018). School, family, and community partnerships: Your handbook for action. Corwin Press.

Ermisch, J. F., \& Francesconi, M. (2001). Family structure and children's achievements. Journal of Population Economics, 14(3). 249-270.

Fan, X., \& Chen, M. (2001). Parental involvement and students "academic achievement: a meta-analysis, Educational analysis Review, 12(5), 101-115.

Glewwe, P., \& Jacoby, H. G. (1995). An economic-analysis of delayed primary school enrollment in a low-income country: the role of early-childhood nutrition. Review of Economics and Statistics, 77(4),156-169.

Guerin, N., Reinberg, A., Testu, F., Boulenguiez, S., Mechkouri, M., \& Touitou, Y. (2001). Role of school schedule, age and parental socioeconomic status on sleep duration and sleepiness of Parisian children. Chronobio. Int., 18(6), 1005-1017.

Gustavsen, A.M., 2018. Gender differences in academic achievement: A matter of contextual classroom influence? Int. J. Res. Stud. Educ., 8(1), 1-20. 
Hanes, B. R. (2008). The exploration of socioeconomic status and student achievement at Beverly elementary school (Doctoral dissertation, Marietta College).

Hill, N. E., \& Taylor, L. C. (2004). Parental school involvement and children's academic achievement: Pragmatics and issues. Current directions in psychological science, 13(4), 161-164.

Hill, N. E., Castelino, O. R., Lansford. J. E., Nowlin, E., Dodge, P., Bates, K. A., \& Pettit, G. S. (2004). Parents academic involvement as related to school behaviour, achievement and aspirations: Demographic variations across adolescence. Child development, 75(5), 1491-1509.

Hoover-Dempsey, K. V., Basslet, O. C., \& Brissie, J. S. (1987). Parent involvement: Contributions of teacher, efficacy, school socioeconomic status, and other school characteristics. American Educational Research, 85(4), 287-294.

Hornby, G., \& Blackwell, I. (2018). Barriers to parental involvement in education: an update. Educational review, 70(1), 109-119.

Izzo, C., Weissberg, R., Kasprow, W., \& Fendrich, M. (1999). A longitudinal assessment of teacher perceptions of parent involvement in children's education and school performance. American Journal of Community Psychology, 27(4), 817-839.

Jeynes, W. (2002). Examining the effects of parental absence on the academic achievement of adolescents. Journal of Family and Economic issues, 3(4), 23-34.

Jeynes, W. (2007). The relationship between parental involvement and urban secondary school student academic achievement. Journal of Educational research, 2(1), 57-70.

Jezierski, S., \& Glenda, W. (2019). Changing understandings and expectations of parental involvement in education. Gender and Education 31, 811-26.

Kellaghan, T., Sloane, K., Alvarez, B., \& Bloom, B. S. (1993). Involving parents in home processes and learning. In T., Kellaghan, K., Sloane, B., Alvarez, \& B. S., Bloom. (Eds.), The home environment and school learning: Promoting parental involvement in the education of children (pp. 144-153). San Francisco: Jossey-Bass.

Kushner, U. M., Benson, S., Mudrey-Camino, R., \& Steiner, R. (2010). The relationship between parental involvement, self-regulated learning, and reading achievement of fifth graders: A path analysis using the ECLS-K database. Social Psychology of Education: An International Journal, 13(2), 237-269.

Lanham, M. A. (2002). Schools can't improve without help of parents. Rowman \& Littlefield Publishers.

Lareau, A. (2000). Home advantage: Social class and parental intervention in elementary education (2nd ed.). open press.

Maina, M. J. (2010). Strategies employed by secondary school principals to improve academic performance in Embu West District. Unpublished master of education thesis. Kenyatta University.

Mukherjee, D. (1995). The relationship between socio-economic background and participation in education. Darlinghurst, ACEE Research Monograph No.1.

Omoegun, M. (2007). Effect of parental socio-economic status on parental care and social adjustment in the UBE programme in Lagos State: Implication for counseling. International Journal of Educational Research, 3(2), 81-87.

Peters, H., \& Mullis, N. (1997). The role of family income and sources of income in adolescent achievement. In Duncan, Brooks-Gun (Eds), Consequences of growing up poor (pp 340-381). New York: Russell Sage Foundation.

Poston, D. L., \& Falbo, T. (1990). Academic Performance and personality traits of Chinese children: "Onlies" versus others. American Journal of Sociology, 96(2) 433451. 
Pruitt, T. S., Nicholas-Omoregbe, S. O., Bergdahl, J., Nomoregbe, N., \& Mbarika, V. (2019). Effects of economic inequality on academic achievement: The Black boy dilemma. EURASIA Journal of Mathematics, Science and Technology Education, 15(3), em1683.

Rothestein, R. (2004). Class and schools using social economic and educational reforms to close the white and black achievement gap. Economic Policy Institute, U.S.A.

Saifi, S., \& Mehmood, T. (2011). Effects of socio-economic status on students achievement. International journal of Education policy, 33(5), 33-56.

Sirin, S. R. (2005). Socioeconomic status and academic achievement: Ameta-analytic review of research. Review of educational research, 7(4),101-115.

Taiwo, H. G. (1993). Family environment and educational attainment of some school children in Western Nigeria. Journal of the Science Teachers Association of Nigeria, 46(2), 107-116.

Trizard, J., Schofield, W. N., \& Hewison, J. (1982). Collaboration between teachers and parents in assisting children's reading. Journal of Child Development, 9(11), 334-354.

Wang. (2010). changes of China's environmental policies in the latest 30 years. Procsedia Environ Sci, 2(4), 1206-1212.

WEF (World economic forum). (2017). The Global Competitiveness Report 2017-2018. http://reports.weforum.org/global-competitiveness-index-2017-2018/ competitiveness

World Bank. (2002). Georgia Poverty Update (Report No. 22350-GE).

World Bank. (2003). Social Analysis Sourcebook: Incorporating Social Dimensions into World Bank Operations. Social Development Department, World Bank: Washington, DC. http://www.worldbank.org/socialanalysis sourcebook 